\title{
MONITORING KEJADIAN INFEKSI VIRAL NERVOUS NECROSIS (VNN) PADA LARVA DAN YUWANA IKAN KERAPU DAN KAKAP MERAH PADA PEMELIHARAAN DENGAN SISTEM TERTUTUP
}

\author{
Ketut Mahardika, Zafran, dan Regina Melianawati
}

\begin{abstract}
ABSTRAK
Ikan kerapu dan kakap merah merupakan salah satu komoditas perikanan yang memiliki nilai ekonomis tinggi. Dalam budi daya ikan ini kendala yang sering dihadapi adalah tingkat kematian yang masih tinggi terutama pada stadia larva hingga yuwana. Kematian massal ini selain disebabkan faktor lingkungan dan pakan, juga diduga disebabkan oleh Nodavirus (famili Nodaviridae) sebagai agen penyebab viral nervous necrosis (VNN). Tujuan dari penelitian ini adalah untuk memonitor kejadian infeksi VNN pada larva dan yuwana ikan kerapu dan kakap merah yang dipelihara dengan sistem tertutup di Balai Besar Riset Perikanan Budidaya Laut, Gondol yang dideteksi dengan metode polymerase chain reaction $(P C R)$ menggunakan primer spesifik. Selama akhir bulan Juli 2002 sampai Oktober 2003, telah dianalisis sampel ikan kerapu (kerapu macan, E. fuscoguttatus dan kerapu lumpur, E. coioides) dan kakap merah (L. sebae dan $L$. argentimaculatus). Organ yang diambil adalah seluruh tubuh untuk larva sebanyak $25-75$ ekor dan mata serta otak untuk yuwana sebanyak 10-20 ekor. Hasil analisis menunjukkan bahwa kedua jenis ikan kerapu tersebut pernah positif terinfeksi VNN, sedangkan kedua jenis ikan kakap merah belum pernah terinfeksi VNN secara alami walaupun dipelihara pada sistem yang sama.
\end{abstract}

ABSTRACT: Monitoring the occurrence of VNN infection in grouper and snapper reared in closed system. By: Ketut Mahardika, Zafran, and Regina Melianawati

Grouper and snapper are economically important fish commodity. The main problem faced is high mortality level of larval until juvenile stage. This mass mortality is caused not only by environmental factors and feed but also by nodavirus infection of viral nervous necrosis (VNN). The aim of this study is to monitor the occurrence of VNN infection in several fish species belonging to groupers and red snappers reared in closed system in Gondol Research Institute for Mariculture, detected by polymerase chain reaction (PCR) method with specific primers. From the end of July 2002 to October 2003, samples of grouper (Epinephelus fuscoguttatus and E. coioides) and snapper (Lutjanus sebae and L. argentimaculatus) were analyzed with PCR. Whole body of 2575 larvae, eye and brain of 10-20 juveniles were used for analysis. The result showed that both species of groupers were positively infected by VNN where as red snappers were negatively infected by VNN infection. It is suggested that two species of grouper were sensitive for VNN infection but two species of red snapper have never been naturally infected by VNN although they were reared in the same system.

KEYWORDS: E. fuscoguttatus, E. coioides, L. sebae, L. argentimaculatus, VNN, PCR

\section{PENDAHULUAN}

Kasus VNN atau viral enchephalopathy and retinopathy (VER) pertama kali dilaporkan pada Japanese parrotfish, Oplegnathus fasciatus, di Jepang (Yoshikoshi \& Inoue, 1990) dan barramundi, Lates calcarifer, di Australia (Glazebrook et al., 1990). Selanjutnya, penyakit ini dilaporkan telah menyerang ikan laut, meliputi 19 spesies, bahkan mungkin lebih, termasuk ke dalam 10 famili ikan laut dari Indo-pasifik, Mediterranean, dan Skandinavia (Munday \& Nakai,
1997). Penyakit ini juga dilaporkan menginfeksi beberapa jenis ikan kerapu di Asia Tenggara meliputi Singapura, Taiwan, Thailand, dan Indonesia.

Di Indonesia, infeksi VNN dilaporkan terjangkit pada kakap putih yang dipelihara di panti benih di Jawa Timur pada tahun 1997 dan panti benih swasta di Bali pada tahun 1998 (Zafran et al., 1998). Pada tahun yang sama, VNN terjadi pada larva dan yuwana kerapu bebek, $C$. altivelis di panti benih swasta di Bali, dengan mortalitas mencapai 100\% (Zafran et al., 2000). 
Agen penyebab dari VNN termasuk ke dalam famili Nodaviridae (Mori et al., 1992). Famili Nodaviridae memiliki dua genus yang meliputi: Alphanodavirus, terutama menginfeksi golongan insekta dan Betanodavirus menginfeksi golongan ikan (Van Regenmortel et al., 2000). Nodavirus ikan dapat diklasifikasikan ke dalam empat genotif yaitu: tiger puffer nervous necrosis virus (TPNNV), striped jack nervous necrosis virus (SJNNV), barfin flounder nervous necrosis virus (BFNNV), dan red-spotted grouper nervous necrosis virus (RGNNV) (Nishizawa et al., 1997).

Deteksi dini infeksi VNN sangatlah penting sebagai upaya pencegahan terhadap penyebaran virus tersebut. Beberapa metode untuk mendeteksi keberadaan virus ini telah ada yaitu antara lain dengan preparat histopatologi, elektron mikroskop, fluorescent antibody technique (FAT), Elisa, dan PCR.

Di Balai Besar Riset Perikanan Budidaya Laut (BBRPBL)-Gondol, telah dikembangkan pemeliharaan benih ikan menggunakan sistem tertutup. Dalam penerapan sistem ini diperlukan kontrol manajemen secara ketat termasuk monitoring mikroorganisme penyebab penyakit yang salah satunya adalah virus VNN. Monitoring VNN sangat diperlukan karena wilayah perairan Bali bagian utara merupakan daerah endemik virus ini, sehingga sewaktu-waktu virus ini dapat menyerang ikan yang dalam kondisi kurang sehat/stres akibat lingkungan, pakan maupun mikroorganisme lainnya.

Adapun tujuan dari penelitian ini adalah untuk memonitor kejadian infeksi VNN pada larva dan yuwana ikan kerapu (kerapu macan, E. fuscoguttatus dan kerapu lumpur, E. coioides) dan kakap merah ( $L$. sebae dan $L$. argentimaculatus) pada perbenihan dan budi daya dengan sistem tertutup. Informasi ini sangat diperlukan dalam pemilihan spesies yang cocok dipelihara dalam sistem tertutup, terkait dengan kemampuannya bertahan terhadap infeksi VNN.

\section{BAHAN DAN METODE}

\section{Pemeliharaan Larva dan Yuwana}

Pemeliharaan larva dilakukan dalam ruang hatcheri yang berada dalam kondisi ruang (indoor). Tangki pemeliharaan larva terdiri atas dua jenis, yaitu tangki test dan tangki produksi yang masing-masing berkapasitas $500 \mathrm{~L}$ dan $4.000 \mathrm{~L}$. Kedua jenis tangki tersebut terbuat dari bahan polyethylene, berwarna hitam dan berbentuk kerucut pada bagian dasarnya. Pencahayaan untuk masing-masing tangki berasal dari lampu TL 40 watt dan lampu halogen 100 watt. Intensitas cahaya di permukaan air tersebut diatur sebesar 800 lux dan pencahayaan ini dilakukan selama 24 jam.

Pemberian pakan alami bagi larva mulai dilakukan pada hari ketiga dengan menggunakan rotifer (Brachionus rotundiformis) dan copepod (Tisbe holothuriaea). Penambahan fitoplankton dilakukan bersamaan dengan pemberian pakan alami. Pakan buatan mulai diberikan pada hari kedua belas atau disesuaikan dengan perkembangan morfologi dari larva itu sendiri. Pada prinsipnya, pemeliharaan larva dilakukan sesuai dengan standar baku dalam pemeliharaan larva (Tridjoko, 1999).

Pemeliharaan yuwana dilakukan dalam ruang weaning dan menggunakan tangki fiberglass berkapasitas $4.000 \mathrm{~L}$. Pakan yang digunakan adalah jenis pakan komersial. Pemberian pakan dilakukan sebanyak tiga kali sehari yaitu pada pagi, siang, dan sore hari. Jumlah yuwana pada awal pemeliharaan berkisar antara 375 hingga 500 ekor.

\section{Mekanisme Kerja Sistem Tertutup}

Fasilitas pemeliharaan ini menggunakan sistem resirkulasi, di mana masing-masing tangki pemeliharaan dihubungkan dengan sistem filteryang secara umum berfungsi untuk menjaga kualitas air selama periode pemeliharaan larva dan yuwana berlangsung. Dalam sistem ini terdapat tiga buah filter yaitu filter mekanik (mechanical filter), biofilter, dan trickling filter. Setelah melalui ketiga sistem filter tersebut, terdapat pula lampu ultra violet untuk sterilisasi air sebelum air tersebut digunakan kembali dalam tangki pemeliharaan. Dengan penggunaan sistem ini maka dimungkinkan pemeliharaan larva dan yuwana dengan media yang relatif sama dan terjaga kualitasnya.

Filter mekanik merupakan filter pertama untuk air yang berasal dari media pemeliharaan dan berfungsi untuk menyaring keluar partikel-partikel yang terdapat dalam media pemeliharaan tersebut. Filter ini bekerja secara otomatis, baik interval waktu maupun periode lama bekerjanya. Pengontrolan kerja filter ini dilakukan pada papan panel.

Air dalam tangki pemeliharaan akan mengalir keluar dengan sistem gravitasi yang selanjutnya akan masuk ke filter mekanik. Air yang telah melalui filter mekanik selanjutnya akan mengalir masuk dalam sebuah penampungan (reservoir) sebelum dipompakan ke biofilter dan kemudian ke trickling filter. Kedua jenis filter tersebut pada prinsipnya berfungsi untuk dekomposisi bahan organik, pelepasan gas, dan penambahan oksigen terlarut sebelum air tersebut digunakan kembali ke dalam media pemeliharaan (Steenfeldt et al., 2002). Setelah melalui proses 
tersebut air kembali dialirkan ke dalam tangki pemeliharaan dengan pompa.

\section{Sampel}

Sampel larva dan yuwana pada penelitian ini terdiri atas jenis ikan kerapu dan kakap merah. Dari masingmasing jenis ikan tersebut, diamati 2 spesies yaitu kerapu macan ( $E$. fuscogutattus) dan kerapu lumpur (E. coioides), serta $L$. sebae dan $L$. argentimaculatus. Jumlah sampel yang digunakan untuk deteksi VNN pada stadia larva sebanyak $25-75$ ekor, sedangkan untuk stadia yuwana digunakan $10-20$ ekor. Organ yang digunakan adalah seluruh tubuh untuk larva dan mata serta otak untuk yuwana. Sampel dibawa dalam bahan fiksatif (alkohol 70\%) atau dalam keadaan segar (sehat, sakit/moribund atau baru mati).

\section{Deteksi VNN}

Deteksi VNN ini dilakukan pada awal pemeliharaan dan setelah larva maupun yuwana berada dalam tahap pemeliharaan. Infeksi VNN dideteksi dengan metode polymerase chain reaction (PCR) menggunakan primer spesifik. Sampel yang digunakan sebanyak $50-100$ $\mathrm{mg}$ mata dan otak yuwana atau seluruh tubuh pada larva di bawah umur 15 hari serta bagian kepala dari larva di atas 15 hari. Sampel-sampel tersebut dimasukkan ke dalam eppendoff steril.

Adapun tahapan dalam mendeteksi virus adalah: Ekstraksi RNA menggunakan isogen (Iwamoto et al., 1999) sebanyak $1 \mathrm{~mL}$ dan disentrifuse $12.000 \mathrm{~g}$ selama 10 menit pada suhu $4^{\circ} \mathrm{C}$. Supernatannya diambil dan ditambahkan dengan $200 \mathrm{~mL}$ chloroform serta disentrifuse $12.000 \mathrm{~g}$ selama 15 menit pada suhu $4^{\circ} \mathrm{C}$. Lapisan atas diambil dan ditambahkan dengan 500 $\mathrm{mL}$ isopropanol serta disentrifuse $12.000 \mathrm{~g}$ selama 10 menit pada suhu $4^{\circ} \mathrm{C}$. Supernatannya dibuang dan ditambahkan dengan $1 \mathrm{~mL}$ alkohol $70 \%$ serta disentrifuse $12.000 \mathrm{~g}$ selama 10 menit pada suhu $4^{\circ} \mathrm{C}$. Selanjutnya supernatannya dibuang dan dikeringkan dalam alat vakum (desikator) selama 15-20 menit.

Tahapan berikutnya adalah mengamplifikasi atau penggandaan DNA VNN menggunakan spesifik primer yaitu F2 (CgTgTCAgTCATgTgTCgCT) dan R3 (CgAgTCAACACgggTgAAgA), primer tersebut merupakan hasil sekuensing dari Striped Jack Nervous Necrosis Virus (SJNNV), pada T-4 dengan target molekul 426 bp. (Nishizawa et al., 1994). Di dalam amplifikasi, RNA tersebut diubah dahulu kedalam bentuk cDNA dengan bantuan reverse enzim pada suhu $48^{\circ} \mathrm{C}$ selama 45 menit dan $94^{\circ} \mathrm{C}$ selama 2 menit, proses selanjutnya adalah penggandaan CDNA dilakukan sebanyak 25 kali dengan suhu denaturasi $95^{\circ} \mathrm{C}$ selama 40 detik, suhu annealing $55^{\circ} \mathrm{C}$ selama 40 detik dan suhu polimerasasi $72^{\circ} \mathrm{C}$ selama 40 detik, untuk pemantapan dan penyimpanan secara berturutturut adalah $72^{\circ} \mathrm{C}$ selama 5 menit dan $4^{\circ} \mathrm{C}$ hingga digunakan dalam proses selanjutnya.

Untuk mengetahui adanya infeksi virus, hasil amplifikasi PCR selanjutnya di elektrophoresis pada $1,5 \%$ agarose gel selama 25 menit dalam TAE buffer dan diwarnai dengan Ethidium bromida selama 1015 menit. Pembacaan hasil dilakukan dengan UV transilluminator dan difoto sebagai dokumentasi menggunakan kamera polaroid. Teknik deteksi VNN dengan RT-PCR yang dilakukan di BBRPBL, GondolBali telah dimodifikasi sedemikian rupa sehingga mudah dalam pengerjaannya (Yuasa et al., 2001).

\section{HASIL DAN BAHASAN}

Selama satu tahun telah dilakukan monitoring infeksi VNN yang dideteksi dengan metode PCR menggunakan primer spesifik terhadap dua jenis ikan kerapu dan ikan kakap merah yang dibenihkan dan dibudidayakan dengan sistem tertutup. Adapun data lengkap hasil monitoring kejadian infeksi VNN disajikan dalam Tabel 1 dan 2.

Tabel 1 menunjukkan bahwa larva kerapu macan dan larva kerapu lumpur dapat terinfeksi VNN. Virus ini ditemukan menginfeksi larva kerapu macan dan larva kerapu lumpur yang berumur dibawah 20 hari pemeliharaan dengan mortalitas berkisar dari $50 \%$ $80 \%$. Menurut Yuasa et al. (2001), VNN dapat menyerang ikan kerapu bebek umur 10 hari sampai 4 bulan, di mana kematian massal terutama sering terjadi pada larva umur 20-30 hari. Kematian ikan dengan cepat menurun setelah umur 3 bulan, akan tetapi keberadaan virus ini terdeteksi juga pada ikan yang sakit (moribund) umur 1 tahun. VNN juga dapat menginfeksi larva ikan kerapu bebek di bawan umur 10 hari (Mahardika \& Koesharyani, 2002).

Hasil observasi menunjukkan bahwa pada larva ikan kerapu berumur di bawah 20 hari tidak ditemukan gejala khusus, ikan tampak lemah di dasar air dan nafsu makannya berkurang. Hal ini dapat dilihat dari sisa pakan alami pada air pemeliharaan dan tiba-tiba terjadi banyak kematian. Menurut Koesharyani et al (2001), ikan yang terinfeksi virus VNN umumnya menunjukkan gejala tingkah laku berenang yang tidak normal yaitu berputar-putar dan diam di dasar air Lebih jauh dikatakan bahwa terdapat perbedaan gejala klinis pada setiap umur ikan yang terinfeksi VNN yaitu pada stadia larva di bawah umur 20 hari, hanya menunjukkan nafsu makan menurun yang dapat dilihat dari sisa rotifer pada air pemeliharaan. Umur 20-45 hari menunjukkan gejala berenang lemah pada permukaan air. Pada waktu yang sama, ditemukan ikan yang mati di dasar air pemeliharaan. Umur 45 hari sampai 4 bulan, ikan yang sakit terlihat diam di 
Tabel 1. Monitoring infeksi viral nervous necrosis (VNN) pada dua spesies ikan kerapu yang dipelihara dengan sistem tertutup

Table 1. The incidence of viral nervous necrosis (VNN) disease infection in two groupers fish cultured in closed system

\begin{tabular}{|c|c|c|c|}
\hline $\begin{array}{c}\text { Tanggal sampling } \\
\text { Sampling date }\end{array}$ & $\begin{array}{l}\text { Jenis ikan } \\
\text { Fish species }\end{array}$ & $\begin{array}{l}\text { Umur (Age of fish) } \\
\text { Umur hari (Days old) }\end{array}$ & $\begin{array}{c}\text { Hasil tes PCR } \\
\text { PCR test }\end{array}$ \\
\hline $31 / 7 / 2002$ & E. coioides & 05 & + \\
\hline $08 / 07 / 2002$ & E. fuscoguttatus & 01 & - \\
\hline 08/07/2002 & E. coioides & 05 & - \\
\hline $18 / 9 / 2002$ & E. fuscoguttatus & 10 & + \\
\hline $18 / 9 / 2002$ & E. fuscoguttatus & 10 & + \\
\hline 03/05/2003 & E. fuscoguttatus & 01 & - \\
\hline 03/05/2003 & E. fuscoguttatus & 01 & - \\
\hline 03/05/2003 & E. fuscoguttatus & 01 & - \\
\hline $03 / 05 / 2003$ & E. fuscoguttatus & 01 & - \\
\hline $08 / 11 / 2003$ & E. fuscoguttatus & 9 & - \\
\hline $08 / 11 / 2003$ & E. fuscoguttatus & 10 & - \\
\hline $08 / 11 / 2003$ & E. fuscoguttatus & 10 & - \\
\hline $08 / 11 / 2003$ & E. fuscoguttatus & 10 & - \\
\hline $08 / 12 / 2003$ & E. fuscoguttatus & 10 & - \\
\hline $08 / 12 / 2003$ & E. fuscoguttatus & 10 & - \\
\hline $08 / 12 / 2003$ & E. fuscoguttatus & 10 & - \\
\hline $08 / 12 / 2003$ & E. fuscoguttatus & 10 & - \\
\hline $19 / 8 / 2003$ & E. fuscoguttatus & 17 & - \\
\hline $19 / 8 / 2003$ & E. fuscoguttatus & 18 & + \\
\hline $19 / 8 / 2003$ & E. fuscoguttatus & 18 & + \\
\hline $19 / 8 / 2003$ & E. fuscoguttatus & 18 & + \\
\hline $19 / 8 / 2003$ & E. fuscoguttatus & 17 & + \\
\hline $19 / 8 / 2003$ & E. fuscoguttatus & 17 & + \\
\hline $09 / 04 / 2003$ & E. fuscoguttatus & 05 & - \\
\hline $09 / 09 / 2003$ & E. fuscoguttatus & 10 & + \\
\hline 09/09/2003 & E. fuscoguttatus & 39 & - \\
\hline 09/09/2003 & E. fuscoguttatus & 38 & - \\
\hline $10 / 01 / 2003$ & E. fuscoguttatus & 03 & - \\
\hline $10 / 01 / 2003$ & E. fuscoguttatus & 03 & - \\
\hline $10 / 01 / 2003$ & E. fuscoguttatus & 03 & - \\
\hline $10 / 06 / 2003$ & E. fuscoguttatus & 08 & + \\
\hline $10 / 06 / 2003$ & E. fuscoguttatus & 08 & - \\
\hline $10 / 06 / 2003$ & E. fuscoguttatus & 08 & - \\
\hline $10 / 10 / 2003$ & E. fuscoguttatus & 12 & - \\
\hline $10 / 10 / 2003$ & E. fuscoguttatus & 12 & - \\
\hline $10 / 10 / 2003$ & E. fuscoguttatus & 12 & - \\
\hline $13 / 10 / 2003$ & E. fuscoguttatus & 15 & - \\
\hline
\end{tabular}

dasar air selama beberapa hari dan mati. Setelah umur 4 bulan, ikan yang sakit terlihat mengambang di permukaan air dengan pembesaran gelembung renang
Tabel 1 juga menunjukkan bahwa larva ikan kerapu macan yang bebas VNN pada umur 10 hari (No. 11 , 12, dan 13) ternyata terinfeksi setelah umur 18 hari (No. 19, 20, dan 21). Demikian pula bebas VNN pada 
umur 3 hari (No. 28), ternyata terinfeksi setelah umur 8 hari (No. 31), namun 4 hari kemudian sisa larva yang masih hidup menunjukkan pemulihan kembali dengan hasil deteksi PCR yang negatif VNN (No. 34).

Pada penelitian ini tidak diamati dari mana jalur masuk virus penyebab VNN ke dalam sistem pemeliharaan larva dan yuwana. Secara teori, VNN mungkin terbawa melalui telur tapi dalam jumlah sedikit sehingga tidak terdeteksi melalui uji PCR atau mungkin juga melalui pakan alami. Sedangkan pemicu terjadinya infeksi VNN pada larva kerapu macan dan kerapu lumpur yang dipelihara dengan sistem tertutup diduga disebabkan oleh faktor lingkungan dan stres.

Pemeliharaan dua spesies ikan kakap merah dalam sistem tertutup (Tabel 2) selama kurang lebih setahun tidak ditemukan adanya infeksi VNN, walaupun terjadi kematian (Tabel 2, No. 2, 3, dan 4) dan setelah dideteksi dengan PCR ternyata negatif terinfeksi VNN. Hal tersebut menunjukkan bahwa kematian pada post-larva ikan kakap merah tidak

Tabel 2. Monitoring infeksi viral nervous necrosis (VNN) pada dua spesies ikan kakap merah yang dipelihara dengan sistem tertutup

Table 2. The incidence of viral nervous necrosis (VNN) disease infection in two snapper fish cultured in closed system

\begin{tabular}{|c|c|c|c|}
\hline $\begin{array}{l}\text { Tanggal sampling } \\
\text { Sampling date }\end{array}$ & $\begin{array}{l}\text { Jenis ikan } \\
\text { Fish species }\end{array}$ & $\begin{array}{c}\text { Umur (hari) } \\
\text { Age of fish (days) }\end{array}$ & $\begin{array}{c}\text { Hasil test PCR } \\
\text { PCR test }\end{array}$ \\
\hline $23 / 8 / 2002$ & L. sebae & 1 & - \\
\hline $23 / 8 / 2002$ & L. sebae (healthy) & 33 & - \\
\hline $23 / 8 / 2002$ & L. sebae (sick) & 33 & - \\
\hline $23 / 8 / 2002$ & L. sebae (dead) & 33 & - \\
\hline $10 / 9 / 2002$ & L. sebae & 0 & - \\
\hline $3 / 10 / 2002$ & L. sebae & 11 & - \\
\hline $3 / 10 / 2002$ & L. sebae & 12 & - \\
\hline $31 / 10 / 2002$ & L. sebae & 0 & - \\
\hline $31 / 10 / 2002$ & L. sebae & 105 & - \\
\hline $7 / 11 / 2002$ & L. sebae & 8 & - \\
\hline $18 / 11 / 2002$ & L. sebae & 19 & - \\
\hline $21 / 11 / 2002$ & L. sebae & 22 & - \\
\hline $23 / 11 / 2002$ & L. sebae & 24 & - \\
\hline $11 / 12 / 2002$ & L. sebae & 138 & - \\
\hline $11 / 12 / 2002$ & L. argentimaculatus & 1 & - \\
\hline $11 / 2 / 2003$ & L. argentimaculatus & 8 & - \\
\hline $11 / 2 / 2003$ & L. argentimaculatus & 10 & - \\
\hline $19 / 2 / 2003$ & L. argentimaculatus & 16 & - \\
\hline $19 / 2 / 2003$ & L. argentimaculatus & 18 & - \\
\hline $19 / 2 / 2003$ & L. argentimaculatus & 18 & - \\
\hline $5 / 3 / 2003$ & L. argentimaculatus & 30 & - \\
\hline $5 / 3 / 2003$ & L. argentimaculatus & 32 & - \\
\hline $6 / 3 / 2003$ & L. argentimaculatus & 33 & - \\
\hline $6 / 3 / 2003$ & L. argentimaculatus & 33 & - \\
\hline $5 / 6 / 2003$ & L. argentimaculatus & 10 & - \\
\hline $5 / 6 / 2003$ & $L$. argentimaculatus & 10 & - \\
\hline $5 / 6 / 2003$ & L. argentimaculatus & 10 & - \\
\hline $5 / 6 / 2003$ & L. argentimaculatus & 10 & - \\
\hline $5 / 6 / 2003$ & L. argentimaculatus & 10 & - \\
\hline $10 / 6 / 2003$ & $L$ L. argentimaculatus & 15 & - \\
\hline $15 / 6 / 2003$ & $L$ L. argentimaculatus & 20 & - \\
\hline
\end{tabular}

Keterangan (Note):

$+\quad$ positif terinfeksi VNN (Positively infected by VNN)

- $\quad$ tidak terinfeksi VNN (Negatively infected by VNN) 
disebabkan oleh infeksi VNN, kemungkinan disebabkan oleh faktor lingkungan atau pakan.

Tabel 2 juga menunjukkan bahwa kedua spesies benih ikan kakap merah lebih tahan terhadap infeksi VNN dibandingkan dengan benih ikan kerapu, meskipun dipelihara dalam satu sistem. Hal tersebut berbeda dengan ikan kakap putih, Lates calcarifer yang dilaporkan pernah terinfeksi VNN (Zafranet al., 1998).

Dari analisis PCR terhadap sampel larva ikan kerapu macan dan lumpur tersebut menunjukkan positif terinfeksi VNN. Hal ini ditandai dengan penampakan pita tunggal dengan berat molekul 426 bp pada agarose gel (Gambar 1).

VNN sampai saat ini masih menjadi kendala utama dalam perbenihan ikan kerapu karena penyakit ini secara cepat dapat menyebar dan menimbulkan kematian massal. Untuk itu perlu dilakukan deteksi dini terhadap virus ini dalam upaya mencegah penyebaran dan kerugian yang ditimbulkannya. Penyebaran virus ini dapat terjadi secara horizontal yaitu dari ikan sakit ke ikan sehat dan secara vertikal yaitu dari induk kepada keturunannya. Penularan secara horizontal dapat terjadi akibat kontaminasi dari bak yang tidak didesinfeksi, alat yang digunakan tidak dibersihkan dengan baik atau manusia. Lebih lanjut Glazebrook et al. (1990) melaporkan bahwa infeksi VNN dapat ditularkan secara horizontal dari larva sakit kepada yang sehat dalam waktu 4 hari. Selanjutnya menurut Mushiake et al. (1994), deteksi SJNNV dari gonad dengan metode PCR sebelum spawning berhasil dalam mencegah transmisi vertikal virus ini. Kontaminasi secara vertikal (dari induk ke larva) mungkin juga terjadi apabila induk-induk tersebut dipacu untuk terus-menerus memijah guna menghasilkan telur. Oleh karena itu, deteksi dini VNN pada larva kerapu merupakan hal penting untuk menjamin bahwa larva yang akan dipelihara benarbenar bebas dari infeksi VNN. Pada pembenihan menggunakan sistem tertutup, benih yang ditebar harus negatif VNN karena sistem ini menggunakan air dengan sistem resirkulasi dengan sedikit penambahan air baru. Apabila terjangkit suatu penyakit maka semua sistem akan terkontaminasi, walaupun telah menggunakan filter mekanik namun virus VNN mampu melalui dan menginfeksi benih ikan kerapu yang dipelihara dalam sistem ini.

\section{KESIMPULAN}

Hasil monitoring VNN pada ikan kerapu dan kakap merah yang dipelihara dengan sistem tertutup menunjukkan bahwa:

Teknologi perbenihan ikan dengan sistem tertutup yang dikembangkan di BBRPBL, Gondol-Bali masih dihadapkan pada masalah infeksi virus yaitu infeksi VNN

Ikan kerapu macan dan kerapu lumpur yang dipelihara dalam sistem ini masih dapat terinfeksi VNN terutama pada stadia larva. Sedangkan dua jenis ikan kakap

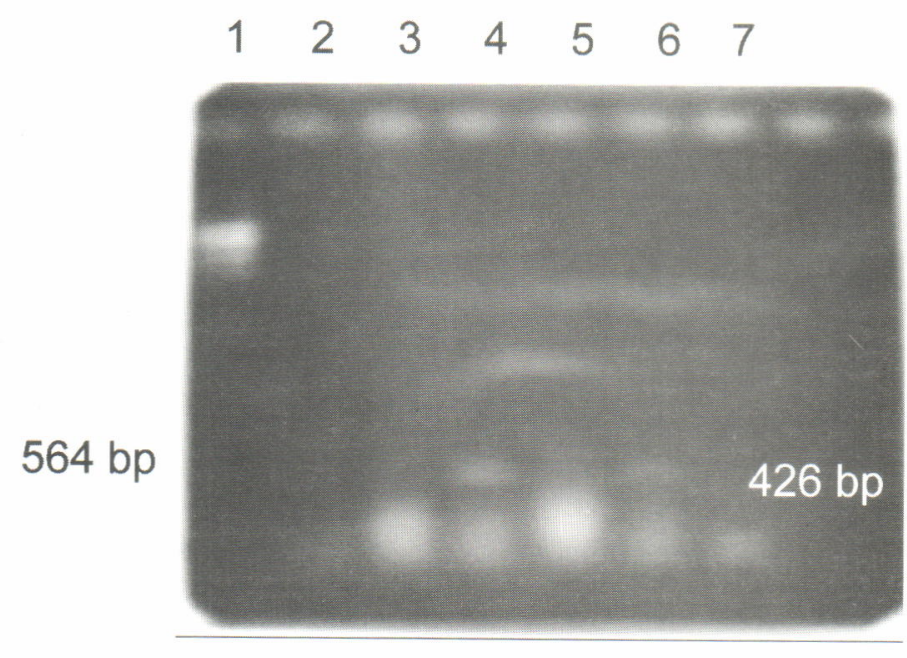

Gambar 1. Gel agarose electrophoresis RT-PCR hasil amplifikasi dari benih ikan kerapu macan, E. fuscoguttatus (tanggal 4 dan 9 September 2003). 1: Marker (I Hind III); 2: umur 5 hari (D-5); 3: umur 39 hari (D-39); 4: umur 10 hari (D-10); 5: umur 38 hari (D-38); 6: kontrol positif; 7: kontrol negatif

Figure 1. Agarose gel electrophoresis of RT-PCR amplification product from tiger groupers fish. E. fuscoguttatus (September 4 and 9, 2003). Line 1: Marker ((I Hind III); 2: 5 days old (D-5); 3: 39 days old (D-39); 4: 10 days old (D-10); 5: 38 days old (D-38); 6: positive control; 7: negative control 
merah selama dilakukan monitoring tidak ditemukan adanya infeksi VNN secara alami, walaupun dipelihara dalam satu sistem dengan ikan kerapu

\section{DAFTAR PUSTAKA}

Glazebrook, J.S., M.P. Heasman, and S.W. de Beer. 1990 Picorna-like viral particles associsted with mass mortalities in larval barramundi, Lates calcarifer Bloch. Journal of Fish Diseases, 13: 245-249.

Iwamoto, T., K. Mori, M. Arimoto, and T. Nakai. 1999. High permissivity of the fish cell line $S S N-1$ for Piscine nodaviruses. Dis. Aquat. Organism., 39: 37-47.

Koesharyani, I., D. Roza, K. Mahardika, F. Johnny, Zafran, and K. Yuasa. 2001. Manual for fish disease diagnosis-II. Reserch Institute for Mariculture, Central Research Institute for Fisheries and Japan International Cooperation Agency, 48 pp.

Mahardika, K. dan I. Koesharyani. 2002. Deteksi awal viral nervous necrosis pada larva kerapu bebek dengan metode Polymerase Chain Reaction. Kumpulan Makalah Kongres III Konsorsium Bioteknologi (KBI) dan Seminar Bioteknologi 2002. Tema Pengembangan Bioteknologi untuk Meningkatkan Nilai Tambah Sumberdaya Hayati. ITB Bandung, 10-11 Oktober 2002, 8 pp.

Mori, K., T. Nakai, K. Muroga, M. Arimoto, K. Mushiake, and I. Furusawa. 1992. Properties of a new virus belonging to nodaviridae found in larval striped jack (Pseudocaranx dentex) with nervous necrosis. Virology, 187: 368-371.

Munday, B.L. and T. Nakai. 1997. Special topic review: Nodavirus as pathogen in larval and juvenile marine finfish. Word Journal of Microbiology and Biotechnology, 13: 375-381.

Mushiake, K., T. Nishizawa, and T. Nakai. 1994. Control of VNN in striped jack: selection of spawnwers based on the detection of SJNNV gene by polymerase chain reaction (PCR). Fish Pathology, 29 (3), 9, 177-182.

Nishizawa, T., K.I. Mori, T. Nakai, I. Furusawa, and K. Muroga. 1994. Polymerase Chain Reaction (PCR) amplification of RNA of Striped Jack Virus Nervous Necrosis (SJVNN). Dis. Aquat. Org., 18: 103-107.

Nishizawa, T., M. Furuhashi, T. Nagai, T. Nakai, and K. Muroga. 1997. Genomic Classification of fish Nodavirus by Molecular Phylogenetic analysis of the Coat protein. Gene. Appl. Environ. Microbiol., 63 1,633-1,636.

Steenfeldt, S., P.B. Pedersen, A. Jokumsen, A. Jokumsen, and I. Lund. 2002. Hatchery production of tropical marine fish in recirculation system. Training Course. DIFRES. The North Sea Center, Denmark, 103 pp

Tridjoko. 1999. Teknologi pembenihan ikan kerapu bebek, Cromileptes altivelis dalam menunjang usaha agroindustri. Prosiding Seminar Nasional Hasil Pengkajian dan Penelitian Teknologi Pertanian Menghadapi Era Otonomi Daerah. Pusat Penelitian Sosial Ekonomi Pertanian. Palu, p. 762-770.

Van Rogenmortel M.H.V., C.M. Fauquet, D.H.L. Bishop, E.B. Carstens, M.K. Ester, S.M. Lemon, J. Maniloff, M.A. Mayo, D.J. McGeoch, C.L. Pringle, and R.B. Wickner (Eds.). 2000. Virus Taxonomy, Classification and Nomenclature of Viruses $7^{\text {th }}$ edn. Academic Press, San Diego, CA.

Yoshikoshi, K. and K. Inoue. 1990. Viral nervous necrosis in hatchery-reared larvae and juveniles of Japanese parrotfish, Oplegnathus fasciatus (Temminck and Schlegel). Journal of Fish Diseases, 13: 69-77.

Yuasa, K., I. Koesharyani, D. Roza, K. Mahardika, F. Johnny, and Zafran. 2001. Manual for PCR procedure: Rapid diagnosis on Viral Nervous Necrosis (VNN) in Grouper. Lolitkanta-JICA Booklet No. 13, 35 pp.

Zafran, T. Harada, I. Koesharyani, K. Yuasa, and K. Hatai. 1998. Indonesian hatchery reared sea bass larvae (Lates calcarifer), associated with viral nervous necrosis (VNN). IFR Journal, IV (I): 19-22.

Zafran, I. Koesharyani, F. Johnny, K. Yuasa, T. Harada, and K. Hatai. 2000. Viral nervous necrosis in humpback grouper Cromileptes altivelis larvae and juveniles in Indonesia. Fish Pathology, 35(2): 9596. 
